\title{
ATR-Interacting Protein
}

National Cancer Institute

\section{Source}

National Cancer Institute. ATR-Interacting Protein. NCI Thesaurus. Code C106415.

AT R-interacting protein (791 aa, $\sim 86 \mathrm{kDa}$ ) is encoded by the human ATRIP gene. This protein is involved in signaling during the DNA damage checkpoint of the cell cycle. 